\title{
Serum neuron-specific enolase as predictor of outcome in comatose cardiac-arrest survivors: a prospective cohort study
}

Cédric Daubin ${ }^{1 *}$, Charlotte Quentin², Stéphane Allouche ${ }^{3,4}$, Olivier Etard ${ }^{5}$, Cathy Gaillard ${ }^{6}$, Amélie Seguin ${ }^{1}$, Xavier Valette ${ }^{1}$, Jean-Jacques Parienti ${ }^{6,7}$, Fabrice Prevost ${ }^{1}$, Michel Ramakers ${ }^{1}$, Nicolas Terzi ${ }^{8,9}$, Pierre Charbonneau ${ }^{1}$ and Damien du Cheyron ${ }^{1,10}$

\begin{abstract}
Background: The prediction of neurological outcome in comatose patients after cardiac arrest has major ethical and socioeconomic implications. The purpose of this study was to assess the capability of serum neuron-specific enolase (NSE), a biomarker of hypoxic brain damage, to predict death or vegetative state in comatose cardiacarrest survivors.

Methods: We conducted a prospective observational cohort study in one university hospital and one general hospital Intensive Care Unit (ICU). All consecutive patients who suffered cardiac arrest and were subsequently admitted from June 2007 to February 2009 were considered for inclusion in the study. Patients who died or awoke within the first 48 hours of admission were excluded from the analysis. Patients were followed for 3 months or until death after cardiopulmonary resuscitation. The Cerebral Performance Categories scale (CPC) was used as the outcome measure; a CPC of 4-5 was regarded as a poor outcome, and a CPC of 1-3 a good outcome.

Measurement of serum NSE was performed at $24 \mathrm{~h}$ and at $72 \mathrm{~h}$ after the time of cardiac arrest using an enzyme immunoassay. Clinicians were blinded to NSE results.

Results: Ninety-seven patients were included. All patients were actively supported during the first days following cardiac arrest. Sixty-five patients (67\%) underwent cooling after resuscitation. At 3 months 72 (74\%) patients had a poor outcome (CPC 4-5) and 25 (26\%) a good outcome (CPC 1-3). The median and Interquartile Range [IQR] levels of NSE at $24 \mathrm{~h}$ and at $72 \mathrm{~h}$ were significantly higher in patients with poor outcomes: NSE at $24 \mathrm{~h}: 59.4 \mathrm{ng} / \mathrm{mL}$ [37106] versus $28.8 \mathrm{ng} / \mathrm{mL}$ [18-41] $(p<0.0001)$; and NSE at $72 \mathrm{h:} 129.5 \mathrm{ng} / \mathrm{mL}$ [40-247] versus $15.7 \mathrm{ng} / \mathrm{mL}$ [12-19] $(p<$ 0.0001). The Receiver Operator Characteristics (ROC) curve for poor outcome for the highest observed NSE value for each patient determined a cut-off value for NSE of $97 \mathrm{ng} / \mathrm{mL}$ to predict a poor neurological outcome with a specificity of 100\% [95\% Cl = 87-100] and a sensitivity of $49 \%$ [95\% Cl $=37-60]$. However, an approach based on a combination of SSEPS, NSE and clinical-EEG tests allowed to increase the number of patients (63/72 (88\%)) identified as having a poor outcome and for whom intensive treatment could be regarded as futile.

Conclusion: NSE levels measured early in the course of patient care for those who remained comatose after cardiac arrest were significantly higher in patients with outcomes of death or vegetative state. In addition, we provide a cut-off value for NSE (> $97 \mathrm{ng} / \mathrm{mL}$ ) with 100\% positive predictive value of poor outcome. Nevertheless, for decisions concerning the continuation of treatment in this setting, we emphasize that an approach based on a combination of SSEPS, NSE and clinical EEG would be more accurate for identifying patients with a poor neurological outcome.
\end{abstract}

\footnotetext{
* Correspondence: daubin-c@chu-caen.fr

'Department of Medical Intensive Care, CHU de Caen, Caen, F-14000, France

Full list of author information is available at the end of the article
}

\section{Biomed Central}

(c) 2011 Daubin et al; licensee BioMed Central Ltd. This is an Open Access article distributed under the terms of the Creative Commons Attribution License (http://creativecommons.org/licenses/by/2.0), which permits unrestricted use, distribution, and reproduction in any medium, provided the original work is properly cited. 


\section{Background}

Despite improvement in resuscitation, the neurological outcome of comatose patients after cardiac arrest remains extremely poor [1]. Therefore, post-resuscitation anoxic encephalopathy represents a common problem with ethical, social, and legal consequences. In clinical practice, intensive care physicians are confronted with the ethical question of whether to continue treatment. In this context, providing predictors of poor outcome (death or permanent vegetative state) with a specificity of $100 \%$ could be useful for early identification of irrecoverable patients for whom intensive treatment could be regarded as futile and palliative care only could be given.

Currently, several clinical parameters and electroencephalographic (EEG) patterns are recognised as being strongly associated with a poor outcome in unsedated comatose survivors of cardiac arrest; these include absence of pupillary or corneal reflexes, absence of extensor motor response to pain 3 days after cardiac arrest, myoclonus or epilepticus status within the first day after resuscitation, and a burst-suppression or isoelectric EEG pattern [1,2]. However, these clinical features and EEG readings could be severely affected by metabolic changes, therapeutic hypothermia or sedative drugs, limiting their clinical relevance for supporting a decision to withdraw active treatment. In contrast, bilateral absence of early cortical response to Somatosensory-Evoked Potentials (SSEPs) recorded on day 1 or later after cardiac arrest accurately predicts a poor outcome with $100 \%$ specificity, regardless of exam conditions [2-7]. However, this electrophysiological procedure is not routinely performed in all ICUs $[8,9]$.

In this context, the serum Neuron-Specific Enolase (NSE), a biomarker of hypoxic brain damage which can be measured easily and reproducibly with minor invasiveness in patients, has recently been assessed as a prognostic predictor after cardiac arrest in several studies [2,9-23]. However, the cut-off points for predicting a poor outcome with no false positives vary greatly ( 9 to $91 \mathrm{ng} / \mathrm{mL}$ ). Differences in definitions of poor outcome, the duration of follow up, the timing of blood sampling and assay procedures could explain these differences.

Therefore, we conducted a prospective cohort study to assess the capability of NSE, measured at fixed times, to predict a poor outcome (death or permanent vegetative state) with certainty in a predefined post cardiac-arrest comatose population.

\section{Methods}

\section{Patients}

We conducted a prospective cohort study of all consecutive non trauma patients who suffered out-of- or inhospital cardiac arrest and were subsequently admitted to the adult intensive care unit in the Caen University Hospital and the Saint Lô General Hospital from June 2007 to February 2009. Patients who died or awoke within the first 48 hours of admission were excluded from this analysis. Therefore, only patients who remained in coma at 48 hours after cardiac arrest were included in the analysis. All patients were followed for 3 months after cardiac arrest or until death.

This study was submitted to the local ethics committee. The ethical board decided that approval was not necessary given the observational nature of this prospective study. Thus, in accordance with French legislation at the time of the study, no informed consent was obtained from the patients.

\section{Assessment of outcome}

Neurological status at 3 months was assessed by telephone interview for patients discharged alive from the intensive care, using the 5-grade Glasgow-Pittsburgh Cerebral Performance Category (GP-CPC) scale [24]. $C P C$ 1: conscious, alert, and oriented with normal cognitive functions, $C P C$ 2: conscious and alert with moderate cerebral disability, $C P C$ 3: conscious with severe disability, CPC 4: comatose or in persistent vegetative state, $C P C$ 5: certified brain death or dead by traditional criteria. A CPC score of 1-3 was considered a good outcome and a CPC of 4-5 a poor outcome.

\section{Measurement of serum NSE}

Blood samples were collected at $24 \mathrm{~h}$ and $72 \mathrm{~h}$ after the time of cardiac arrest. All samples with visible hemolysis were discarded from analysis to avoid any falsely elevated values for serum NSE. Blood was centrifuged at 3 $000 \mathrm{rpm}$ for $10 \mathrm{~min}$. The isolated serum was immediately frozen at $-80^{\circ} \mathrm{C}$ and stored until time of assay. The serum NSE level was measured using a solid-phase immunoassay with double monoclonal antibodies directed against NSE (Roche Diagnostics GmbH, Mannheim, Germany) on an Elecsys instrument. The limit of detection was $0.05 \mathrm{ng} / \mathrm{mL}$ and the institutional normal value was $<16.3 \mathrm{ng} / \mathrm{mL}$. When the NSE level reached $50 \mathrm{ng} /$ $\mathrm{mL}$, the serum was diluted to avoid a hook effect. Clinicians were blinded to NSE results during the entire patient stay. For each patient, the highest measurement of NSE was tested for outcome prediction. Because the $24 \mathrm{~h}$ value is more variable than that at $72 \mathrm{~h}$, we also considered the $72 \mathrm{~h}$ NSE value as the highest observed NSE in the sensitivity analysis.

\section{Data collection}

Clinical variables collected at baseline were: age, sex, underlying diseases, cause of the arrest (cardiac, respiratory, other or unknown), time between arrest and cardiopulmonary resuscitation, initial cardiac rhythm 
(ventricular fibrillation or tachycardia, asystole, pulseless rhythm), duration of cardiopulmonary resuscitation, number of external electric shocks, cumulative epinephrine dose, and scoring of disease severity within the first day in ICU as assessed during admission by the Simplified Acute Physiology Score type II (SAPS II) [25], and number of organ failures according to Knaus criteria [26].

Following our standard of treatment [27], a neurological assessment was daily performed after cardiac arrest using measures of clinical and electrophysiological evaluation. For patients who underwent cooling after resuscitation, clinical and neurophysiological tests, including EEG and SSEPs recording, were performed after warming. For this reason, the findings of the first neurological assessment reported in results section were recorded within $24 \mathrm{~h}-36 \mathrm{~h}$ after resuscitation.

Clinical parameters included pupillary light reflex (present/absent), motor response to painful stimulation (extensor or absent response/other response), corneal reflex (present/absent), tonic-clonic seizures (present/ absent) and myoclonus (present/absent).

Electrophysiological assessment included EEG and Somatosensory-Evoked Potential (SSEP) recordings, routinely performed in our centre. All EEGs and SSEPs were read by an expert neurophysiologist (O.E.). Two EEG were performed: the first within $24 \mathrm{~h}-36 \mathrm{~h}$ after resuscitation and the second at $72 \mathrm{~h}$. EEGs were recorded on a system with at least 10 channels and needle electrodes and used a 10-20 international system (Fp1, Fp2, C3, C4, T5, T6, O1, and O2). The EEG patterns were classified according to the classification system of Synek et al. [28,29]. EEG results were categorised as either malignant (isoelectric, burst-suppression pattern with interburst interval of at least $1 \mathrm{~s}$ and generalised continous epileptiform discharges) or non malignant (other patterns, including alpha and theta coma). SSEPs were performed as soon as possible after the first 24 hours after resuscitation. However, if SSEPs recording was due on a weekend day, the recording was postponed to Monday. SSEPs were recorded on a Medtronic keypoint system using 6 channels: erb'point; C6sp; C'3 or C'4, contralateral to the stimulated hand and $\mathrm{Fpz}$ (ipsilateral ear was used as a reference). The 2 remaining channels served as channel controls: C'3 - C'4 (or C'3-C'4) on which the N20 amplitude was measured, and Fpz-C'3 (or Fpz-C'4) in order to check for a long latency component using a larger time window. Absence of early cortical responses to somatosensory-evoked potentials (N20) were declared only if the 3 following conditions were present: (i) correct peripheral (N10) and medullary (N13) component, (ii) no deflection higher than $0.5 \mu \mathrm{V}$ on C3-C'4 (or C'3-C'4), (iii) no late component on Fpz-C'3 (or Fpz-C'4).

\section{Treatment and treatment restriction}

All patients were actively supported during the first days following cardiac arrest or until SSEP assessment. They received standard intensive care management and monitoring. In addition, in our practice, therapeutic hypothermia (target temperature $33^{\circ} \mathrm{C}$ ) was recommended for all cardiac causes of arrest, regardless of initial rhythm, and left to the assessment of the attending physician for the other causes. The patients who underwent cooling received propofol or midazolam and sufentanyl for sedation and atracurium $(0.5 \mathrm{mg} / \mathrm{kg}$ per hour) to prevent shivering. These drugs were stopped after passive rewarning to a central temperature of $36^{\circ} \mathrm{C}$. Hypothermia was induced using an endovascular cooling catheter (IcyTM, Alsius, Irvine, CA, USA) inserted into the inferior vena cava via the femoral vein and connected to a cooling device (Coolgard 3000TM, Alsius, Irvine, CA, USA), and was maintained for $24 \mathrm{~h}$. In patients with a bilateral lack of cortical response (N20) to SSEPs, further treatment was considered futile and active care was withdrawn. In addition, in accordance with our previous report [27] and recent literature $[1,2,30]$ a decision to withdraw treatment was debated by the medical staff after 5 days in patients with 3 or more pejorative criteria at $72 \mathrm{~h}$; these included: absence of pupillary light reflex or corneal reflex, extensor or absence of motor response to painful stimulation, persistent myoclonus, and a malignant EEG pattern

\section{Statistical analysis}

Categorical variables were reported as counts and percentages. Quantitative data which did not follow a Gaussian curve (NSE levels) were described as median and Interquartile Range [IQR, first quartile - third quartile]. Other qualitative data were reported as mean \pm standard deviation (SD). Means were compared between two groups using Student's $t$-test, and median levels of NSE were compared between two groups using the MannWhitney U test. Percentages were compared using a chi-square test or Fisher exact test for small samples. The discriminative power of the highest measurement of NSE in predicting poor outcome at 3 months (CPC 4-5) was evaluated by Receiver Operating Characteristic (ROC) analysis. Thresholds for NSE are given for 100\% specificity and the highest sensitivity. Area Under the Curve (AUC) is given with 95\% confidence intervals. Finally, the percentage of abnormal test results, false positive rates and positive likelihood ratios with their 95\% confidence interval were calculated. The positive likelihood ratio calculation was made possible by adding 0.5 in the cell when there was no patient with a poor test result and a good outcome [31]. We used EPI-INFO version 6.04 dfr (EPI-INFO, CDC, Atlanta, GA) for data 
collection, and EPI-INFO and SAS version 9.1 (SAS Institute Inc, Cary, NC) for data analysis

\section{Results}

Baseline characteristics and neurological outcome

Of the 149 consecutive patients resuscitated after a cardiac arrest and admitted to the intensive care unit during the study period, 97 fulfilled inclusion criteria for analysis. At 3 months $72(74 \%)$ patients had a poor outcome (CPC 4-5) and 25 (26\%) had a good outcome $(\mathrm{CPC} 1-2, \mathrm{n}=17$ and $\mathrm{CPC} 3, \mathrm{n}=8)$ as shown in Figure 1. All but one death occurred in the ICU, and in $93 \%$ of the cases they were associated with a decision to withdraw active treatment. In patients $(n=67)$ for whom a decision to withdraw active treatment was taken, the survival median time was 5 days [IQR, 4-8]. As expected in these patients, the survival median time was lower in patients $(\mathrm{n}=45)$ with unfavorable SSEP results (4 days [IQR, 3-5]) than in those $(\mathrm{n}=22)$ with favorable SSEP results (13 days [IQR, 7-20]), $\mathrm{p}=0.02$.

Patient baseline characteristics are presented in Table 1. Patients with a poor outcome were older, with more frequent histories of coronary disease or diabetes mellitus and had higher disease severity scores at admission. However, regarding resuscitation time, there was no difference between patients with a good or poor outcome, except for primary cause of cardiac arrest. Sixty-five patients (67\%) underwent cooling after resuscitation: 45 in group CPC $4-5$ and 20 in group CPC 1-3, $p=0.11$.

\section{Serum NSE levels and prediction of poor outcome}

The median levels of NSE at $24 \mathrm{~h}(\mathrm{n}=86)$ and at $72 \mathrm{~h}$ $(n=61)$ and the highest measurement of NSE for each patient were significantly higher in patients with poor outcomes: median 24 h NSE level: $59.4 \mathrm{ng} / \mathrm{mL}$ [IQR, $37-$ $106]$ versus $28.8 \mathrm{ng} / \mathrm{mL}$ [IQR, 18-41] $(p<0.0001)$; median 72 h NSE level: $129.5 \mathrm{ng} / \mathrm{mL}$ [IQR, 40-247] versus $15.7 \mathrm{ng} / \mathrm{mL}$ [IQR, 12-19] $(p<0.0001)$; and highest measurement of NSE: $87.6 \mathrm{ng} / \mathrm{mL}$ [IQR, 44-178] versus 28.8 $\mathrm{ng} / \mathrm{mL}$ [IQR, 19-41] $(p<0.0001)$. The frequency of different neurological outcome categories in relation to the highest individual measurement of NSE concentration of our patients is presented Figure 2.

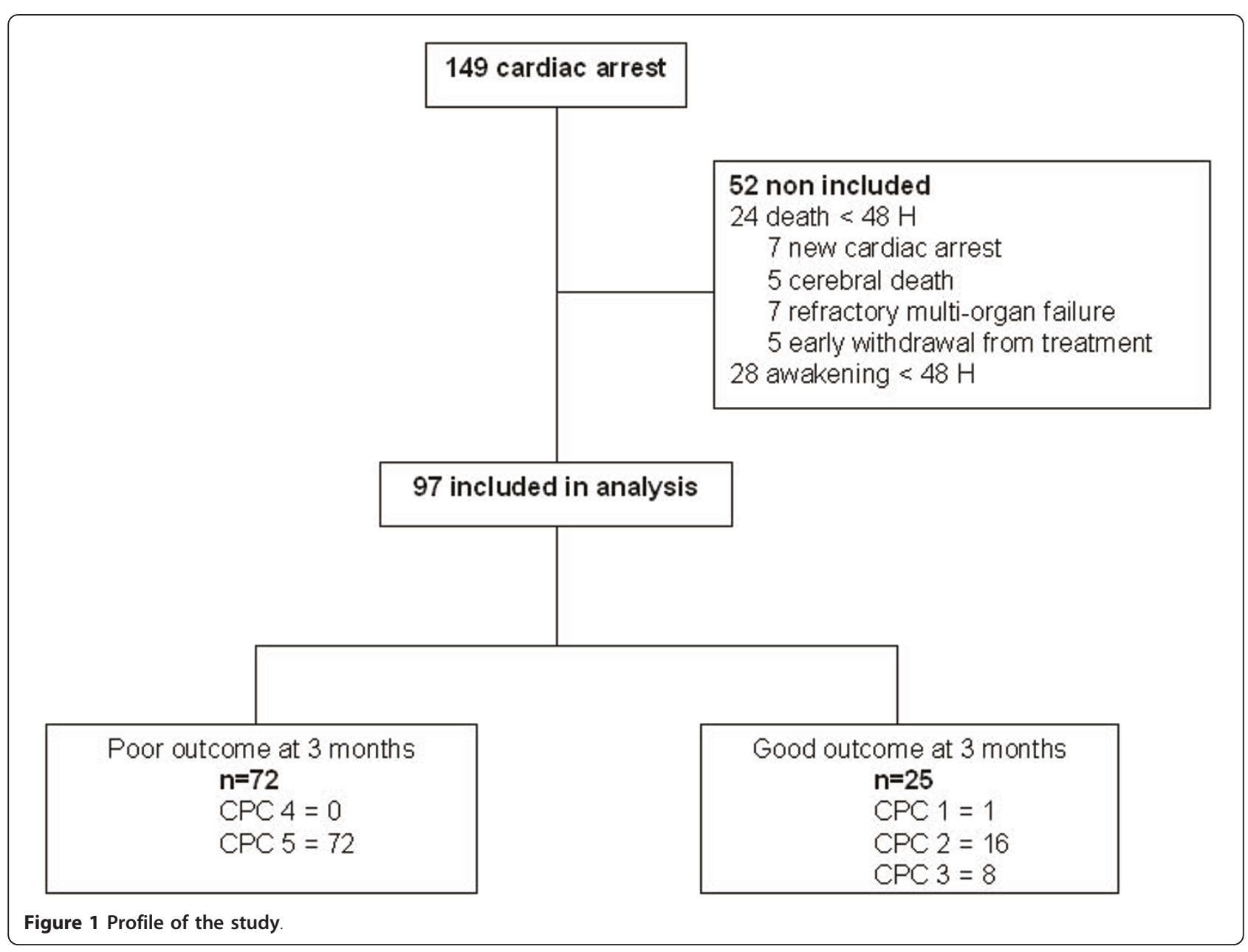




\begin{tabular}{|c|c|c|c|c|}
\hline & $\begin{array}{c}\text { All patients } \\
\mathrm{n}=97\end{array}$ & $\begin{array}{c}\text { Poor outcome } \\
n=72\end{array}$ & $\begin{array}{c}\text { Good outcome } \\
n=25\end{array}$ & $p$ \\
\hline Age (years), mean $\pm S D$ & $57 \pm 16$ & $60 \pm 15$ & $50 \pm 17$ & 0.01 \\
\hline Male, n (\%) & $75(77)$ & $56(78)$ & $19(76)$ & 0.85 \\
\hline \multicolumn{5}{|l|}{ Medical history n (\%) } \\
\hline Neurologic diseases & $11(11)$ & $10(14)$ & $1(4)$ & 0.18 \\
\hline \multicolumn{5}{|l|}{ Cardiovascular diseases } \\
\hline Ischemic & $20(21)$ & $19(26)$ & $1(4)$ & 0.017 \\
\hline Hypertensive & $34(35)$ & $29(40)$ & $5(20)$ & 0.067 \\
\hline Congestive & $12(12)$ & $10(14)$ & $2(8)$ & 0.44 \\
\hline Arrhythmic & $4(5)$ & $3(4)$ & $2(8)$ & 0.82 \\
\hline \multicolumn{5}{|l|}{ Metabolic diseases } \\
\hline Diabetes mellitus & $17(18)$ & $17(24)$ & 0 & 0.007 \\
\hline \multicolumn{5}{|l|}{ Respiratory diseases } \\
\hline COPD & $7(7)$ & $6(8)$ & $1(4)$ & 0.47 \\
\hline \multicolumn{5}{|l|}{ Liver diseases } \\
\hline Cirrhosis & $4(4)$ & $4(6)$ & 0 & 0.53 \\
\hline \multicolumn{5}{|l|}{$\underline{\text { Resuscitation variables }}$} \\
\hline Witnessed CA n (\%) & $77(79)$ & $57(79)$ & $20(80)$ & 0.93 \\
\hline In-hospital CA n (\%) & $30(31)$ & $26(36)$ & $4(16)$ & 0.06 \\
\hline \multicolumn{5}{|l|}{ Primary cause of CA n (\%) } \\
\hline Cardiac & $55(57)$ & $38(53)$ & $17(68)$ & 0.19 \\
\hline Respiratory & $17(18)$ & $16(22)$ & $1(4)$ & 0.04 \\
\hline Other or unknown & $22(23)$ & $17(24)$ & $5(20)$ & 0.7 \\
\hline Time from CA to CPR (minutes) & $5.6 \pm 6.9$ & $6.3 \pm 7.2$ & $3.4 \pm 5.5$ & 0.07 \\
\hline$<3$ n (\%) & $46(51)$ & $31(46)$ & $15(65)$ & \\
\hline $3-5 n(\%)$ & $9(10)$ & $6(9)$ & $3(13)$ & \\
\hline$>5$ n (\%) & $36(40)$ & $31(46)$ & $5(22)$ & \\
\hline Duration of CPR (minutes) & $24.9 \pm 24.2$ & $25.7 \pm 26.6$ & $22.5 \pm 15.7$ & 0.39 \\
\hline$<5$ n (\%) & $9(9)$ & $5(7)$ & $4(16)$ & \\
\hline $5-15$ n (\%) & $18(19)$ & $13(18)$ & $5(20)$ & \\
\hline$>15$ n (\%) & $69(72)$ & $53(75)$ & $16(64)$ & \\
\hline Primary rhythm n (\%) & & & & 0.09 \\
\hline Asystole & $55(57)$ & $46(64)$ & $9(36)$ & \\
\hline VFNT & $35(36)$ & $21(29)$ & $14(56)$ & \\
\hline Pulseless electrical activity & $5(5)$ & $4(6)$ & $1(4)$ & \\
\hline Unknown & $2(2)$ & $1(1,4)$ & $1(4)$ & \\
\hline Number of defibrillations, mean \pm SD & $2.1 \pm 3.1$ & $1.9 \pm 3.3$ & $2.8 \pm 2.4$ & 0.17 \\
\hline Epinephrine mg mean, \pm SD & $5.1 \pm 5.2$ & $5 \pm 4.8$ & $5.6 \pm 6.2$ & 0.62 \\
\hline \multicolumn{5}{|l|}{ ICU admission } \\
\hline SAPS $\|$ mean, \pm SD & $67 \pm 15$ & $69 \pm 15$ & $61 \pm 11$ & 0.006 \\
\hline Shock n(\%) & $59(61)$ & $43(60)$ & $16(64)$ & 0.7 \\
\hline Renal replacement therapy n(\%) & $15(16)$ & $11(15)$ & $4(16)$ & 1 \\
\hline MOF n(\%) & $18(19)$ & $16(22)$ & $2(8)$ & 0.14 \\
\hline Therapeutic hypothermia n(\%) & $65(67)$ & $45(63)$ & $20(80 \%)$ & 0.11 \\
\hline
\end{tabular}

CA, cardiac arrest; COPD, chronic obstructive pulmonary disease; CPR, cardiopulmonary resuscitation; FV ventricular fibrillation; MOF, multi organ failure according to Kraus criteria [27]; SAPS II, Simplified Acute Physiology Score type II; VT, ventricular tachycardia.

In our sample group, the highest measurements of NSE for each patient were not different in patients treated with or without induced hypothermia: $67.4 \mathrm{ng} / \mathrm{mL}$ [IQR, 37.2-143.6] versus $55.3 \mathrm{ng} / \mathrm{mL}$ [IQR, 25.1-159.4] $(p=0.7)$. In addition, no significant difference for the highest measurement of NSE was observed in patients with a good outcome (CPC 1-3) treated with $(n=20)$ or without $(\mathrm{n}=5)$ hypothermia; highest measurement of NSE: $29.6 \mathrm{ng} / \mathrm{mL}$ [IQR, 18.7-46.3; Range, 9.7-91.7 ] versus $19.6 \mathrm{ng} / \mathrm{mL}$ [IQR, 8.5-25.5; Range, 8-37.4], $\mathrm{p}=0.02$, 


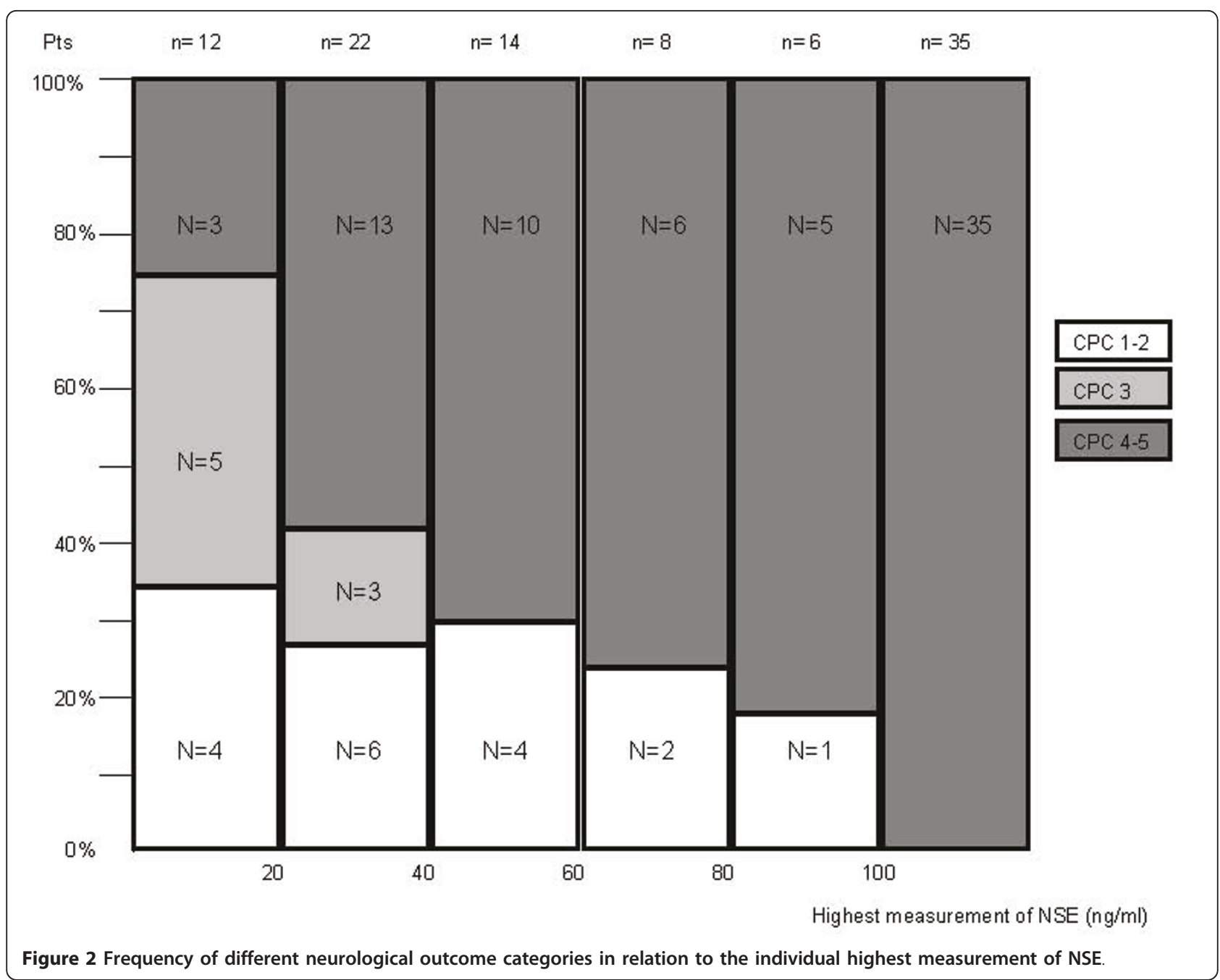

respectively. A similar result was observed in patients with a poor outcome (CPC 4-5): highest measurement of NSE in patients $(\mathrm{n}=45)$ treated with hypothermia 105.7 $\mathrm{ng} / \mathrm{mL}$ [IQR, 48.5-179.7; Range, 16.7-952.3] versus 82.8 $\mathrm{ng} / \mathrm{mL}$ [IQR, 32.5-172.2; Range, 19.5-1071] in patients (n $=27$ ) without therapeutic hypothermia $\mathrm{p}=0.02$.

The ROC curve for poor outcome for the highest measurement of NSE for each patient is presented in Figure 3. The NSE level with the highest specificity and sensitivity was $47 \mathrm{ng} / \mathrm{mL}(\mathrm{Sp}=84 \%$ [95\% CI $=70-98]$, $\mathrm{Se}=72 \%[95 \% \mathrm{CI}=62-83])$ with a positive predictive value of $93 \%$ [95\% CI $=86-100]$. An NSE level $\geq 97 \mathrm{ng} /$ $\mathrm{mL}$ predicted a poor outcome with a positive predictive value of $100 \%$ [ $95 \% \mathrm{CI}=87-100]$ and a sensitivity of $49 \%[95 \% \mathrm{CI}=37-60]$. Interestingly, 32/35 (91\%) and $29 / 35(83 \%)$ of patients with a NSE measurement $>97$ $\mathrm{ng} / \mathrm{mL}$ had unfavorable SSEP results and a malignant EEG pattern at $72 \mathrm{~h}$, respectively, and the 3 and 6 remaining patients had 3 or more unfavorable clinical and electrophysiological criteria, respectively (see below).
The sensitivity analysis provided similar results (see additional file 1: " Receiver operating characteristic curves for $72 \mathrm{~h}$ NSE value $(\mathrm{ng} / \mathrm{mL})$ to predict poor neurological outcome")

Contribution of each clinical, electrophysiological and biological test to prediction of poor outcome

The absence of cortical response to SSEPs was recorded in 45 patients. An unfavorable SSEP result was associated with $2.9 \pm 1$ predefined unfavorable clinicalEEG criteria. In accordance with our treatment restriction policy, all died.

The predictive values of clinical-EEG and biological tests for a poor outcome are presented in Table 2. An NSE level $\geq 97 \mathrm{ng} / \mathrm{mL}(n=35)$, myoclonus at $24 \mathrm{~h}(n=$ $26)$, and absence of pupillary light reflex $(n=18)$ or corneal reflex $(n=31)$, tonic-clonic seizures $(n=6)$ and malignant EEG pattern at $72 \mathrm{~h}(n=32)$ were predictive for a poor outcome with no false positives. Electrophysiological and biological tests had a higher percentage of abnormal test results than clinical tests. 


\section{ROC curve}

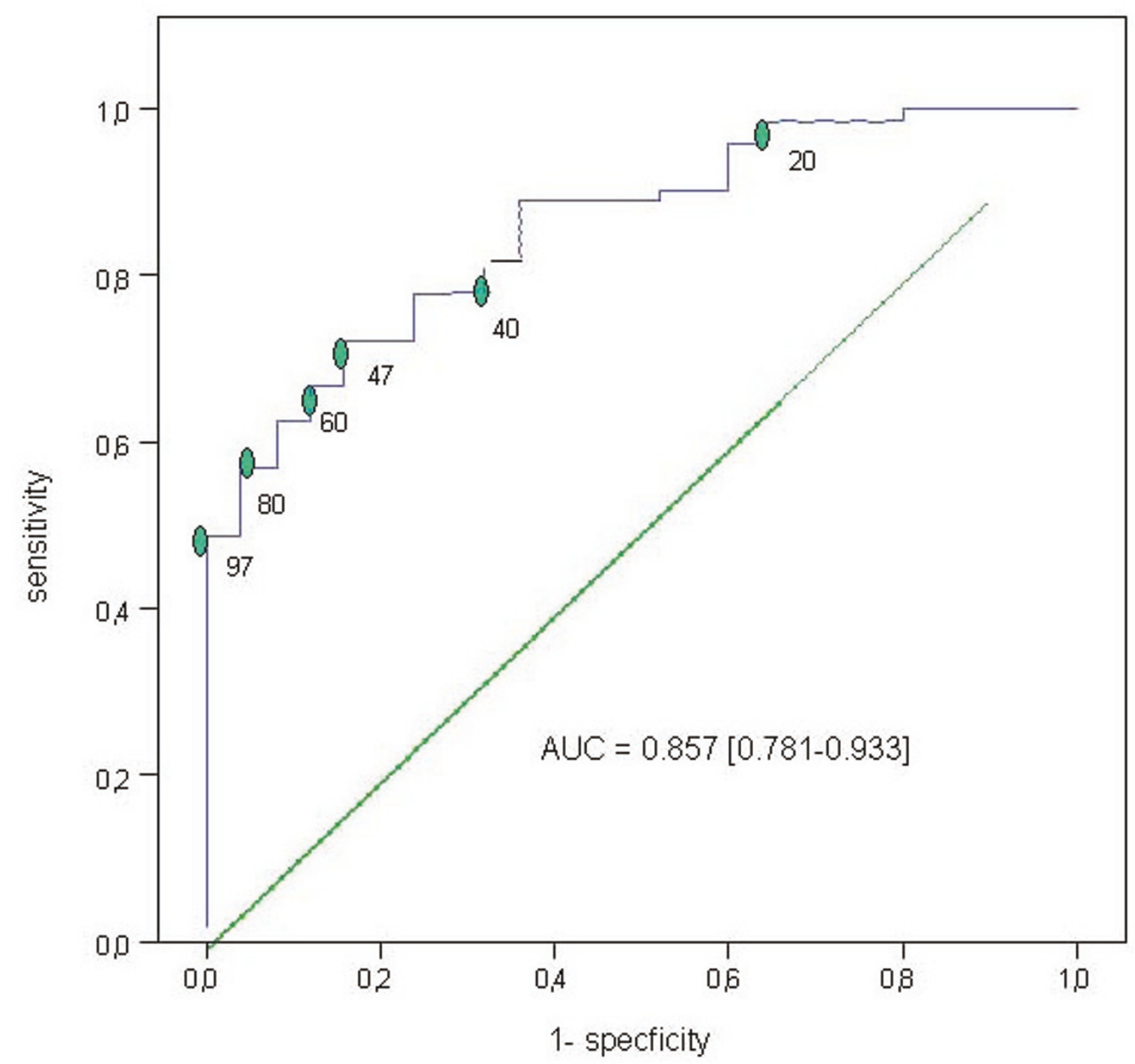

Figure 3 Receiver operating characteristic curves for different peak serum NSE cut-off values (ng/mL) to predict poor neurological outcome.

An approach based on a combination of SSEPs, NSE and clinical-EEG tests increased the number of patients $(63 / 72(88 \%))$ identified as having a poor outcome, as shown in Figure 4.

No tests predicted a good outcome. For example, only $51 \%(24 / 47)$ of our patients with a favorable SSEP result made a good recovery

\section{Discussion}

Considering the poor neurological prognosis of comatose patients after cardiac arrest, physicians are rapidly confronted with the ethical question of whether to continue intensive treatment. To our knowledge, except for unfavorable SSEP results, predictors of poor outcome with a $100 \%$ specificity and a high sensitivity are lacking $[1,2,8]$. Recently, several studies [2,9-23] have investigated the usefulness of increased serum NSE as a marker of poor outcome. In this prospective study, we provide a cut-off value for NSE (> $97 \mathrm{ng} / \mathrm{mL}$ ), measured at a fixed time after cardiac arrest, with $100 \%$ predictive value for a poor neurological outcome (death or vegetative state). However, a strategy based on a combination of SSEPs, NSE and clinical-EEG tests increase the number of patients identified as having a poor outcome. These results may have important implications in determining the level of care to be provided three days after cardiac arrest, involving SSEPs or NSE access, and clinical EEG evaluation. 
Table 2 Prediction of poor outcome with clinical, electrophysiological and biological variables

\begin{tabular}{|c|c|c|c|c|}
\hline & $\begin{array}{l}\text { Patients } \\
\text { tested, } \mathrm{n}\end{array}$ & $\begin{array}{c}\text { Abnormal test result, } \% \\
(95 \% \mathrm{Cl})\end{array}$ & $\begin{array}{l}\text { False positive rate*, \% } \\
(95 \% \text { IC) }\end{array}$ & $\begin{array}{c}\text { Positive likelihood ratio } \\
(95 \% \text { IC) }\end{array}$ \\
\hline \multicolumn{5}{|c|}{ Motor response $\leq 2$} \\
\hline$-24 h-36 h$ & 97 & $87 \%[80 \%-93 \%]$ & $56 \%[45 \%-67 \%$ & $1.7[1.2-2.5]$ \\
\hline$-72 h$ & 87 & $70 \%[61 \%-80 \%]$ & $16 \%[7 \%-25 \%]$ & $5.8\left[\begin{array}{lll}2.3 & -1 & 4.1\end{array}\right]$ \\
\hline \multicolumn{5}{|c|}{ No corneal reflexes } \\
\hline$-24 h-36 h$ & 95 & $40 \%[30 \%-50 \%]$ & $12 \%[2 \%-22 \%]$ & $4.2[1.4-12.4]$ \\
\hline$-72 h$ & 86 & $36 \%[26 \%-46 \%]$ & $0 \%$ [0\%-14\%] & $26[1.7-415]$ \\
\hline \multicolumn{5}{|c|}{ No pupillary reflexes } \\
\hline$-24 h-36 h$ & 97 & $26 \%[17 \%-35 \%]$ & $4 \%[4 \%-12 \%]$ & $8.3[1.2-58]$ \\
\hline$-72 \mathrm{~h}$ & 87 & $21 \%[12 \%-29 \%]$ & $0 \%[0 \%-14 \%]$ & $15[1-244]$ \\
\hline \multicolumn{5}{|l|}{ Myoclonus } \\
\hline$-24 h-36 h$ & 97 & $27 \%[18 \%-36 \%]$ & $0 \%[0 \%-14 \%]$ & 19 [1.2 - 299] \\
\hline$-72 \mathrm{~h}$ & 87 & $23 \%[14 \%-32 \%]$ & $8 \%[4 \%-20 \%]$ & $3.6[1-14]$ \\
\hline \multicolumn{5}{|l|}{ Epilepsy } \\
\hline$-24 h-36 h$ & 97 & $7 \%[7 \%-12 \%]$ & $0 \%[0 \%-14 \%]$ & $5.3[0.3-90]$ \\
\hline$-72 h$ & 87 & $7 \%[2 \%-12 \%]$ & $0 \%[0 \%-14 \%]$ & $5.3[0.31-91]$ \\
\hline \multicolumn{5}{|c|}{ - Malignant EEG ** } \\
\hline$-24-36 h$ & $90^{\pi}$ & $44 \%[34 \%-55 \%]$ & $4 \%[2 \%-10 \%]$ & 14 [2.1-97] \\
\hline$-72 h$ & $73^{99}$ & $44 \%[33 \%-55 \%]$ & $0 \%[0 \%-17 \%]$ & 25 [1.6-394] \\
\hline \multicolumn{5}{|c|}{$\begin{array}{l}\text { Highest measurement of NSE } \geq 47 \\
\mathrm{ng} / \mathrm{mL}\end{array}$} \\
\hline & 97 & $58 \%[48 \%-68 \%]$ & $7 \%[0,4 \%-14 \%]$ & $4.5[1.8-11]$ \\
\hline \multicolumn{5}{|c|}{$\begin{array}{l}\text { Highest measurement of NSE } \geq 97 \\
\mathrm{ng} / \mathrm{mL}\end{array}$} \\
\hline & 97 & $36 \%[27 \%-46 \%]$ & $0 \%[0 \%-13 \%]$ & 25 [1.6-397] \\
\hline
\end{tabular}

* Patients with abnormal test results and good outcome/all patients with abnormal test results (1-positive predictive value)

** included isoelectric and burst-suppression pattern with interburst interval of at least $1 \mathrm{~s}$ and generalised continuous epileptiform discharges

" Forty-four patients were still affected by sedative medication

กศ เพenty-one patients were still affected by sedative medication

In our study, $74 \%$ of the patients who remained comatose after cardiac arrest never regained consciousness. This result is consistent with previous studies [2,32-36] and with our recent publication [27] reporting an early clinical and electrophysiological score with $100 \%$ predictive value for poor outcome in this setting. The proportion of patients (49\%) with no early cortical responses to SSEPs, a result recognized to be the most accurate predictor of a poor outcome in survivors after a cardiac arrest $[2,3,8,34,35,37-39]$, is also consistent with previous reports [2,27,34-36]. We also report that an unfavorable SSEP result was associated with a mean of $2.9 \pm 1$ other pejorative clinical-EEG criteria. In addition, our results confirm that the presence of early cortical responses to SSEPs is a poor predictor of a good outcome, as previously reported $[2,27,34,40]$; indeed, only $51 \%(24 / 47)$ of our patients with a favorable SSEP result made a good recovery. Interestingly, we report that the absence of motor response to painful stimuli has a higher false positive poor outcome prediction compared to the American Academy of Neurology (AAN) meta-analysis [1] and that a malignant EEG is strongly associated with outcome. These findings are consistent with a recent report [41] assessing the prognostic value of clinical and electrophysiological variables in comatose survivors of cardiac arrest treated with therapeutic hypothermia and suggest using caution in the application of AAN guidelines.

NSE levels were significantly higher in comatose cardiac arrest survivors with poor outcome, regardless of the time of measurement. In addition, we identified a cut-off value for NSE (>97 ng/mL), predicting a poor outcome (death or vegetative state) with no false positives. Interestingly, 32/35 (91\%) and 29/35 (83\%) patients with an NSE measurement $>97 \mathrm{ng} / \mathrm{mL}$ had an unfavorable SSEP result and a malignant EEG pattern at $72 \mathrm{~h}$, respectively. These findings argue that NSE measurement may be used, in combination with clinical tests, as a potential substitute for SSEPs and EEG in settings without access to electrophysiological assessment, for early identification of a subgroup of irrecoverable patients for whom continued intensive care could be considered futile. 


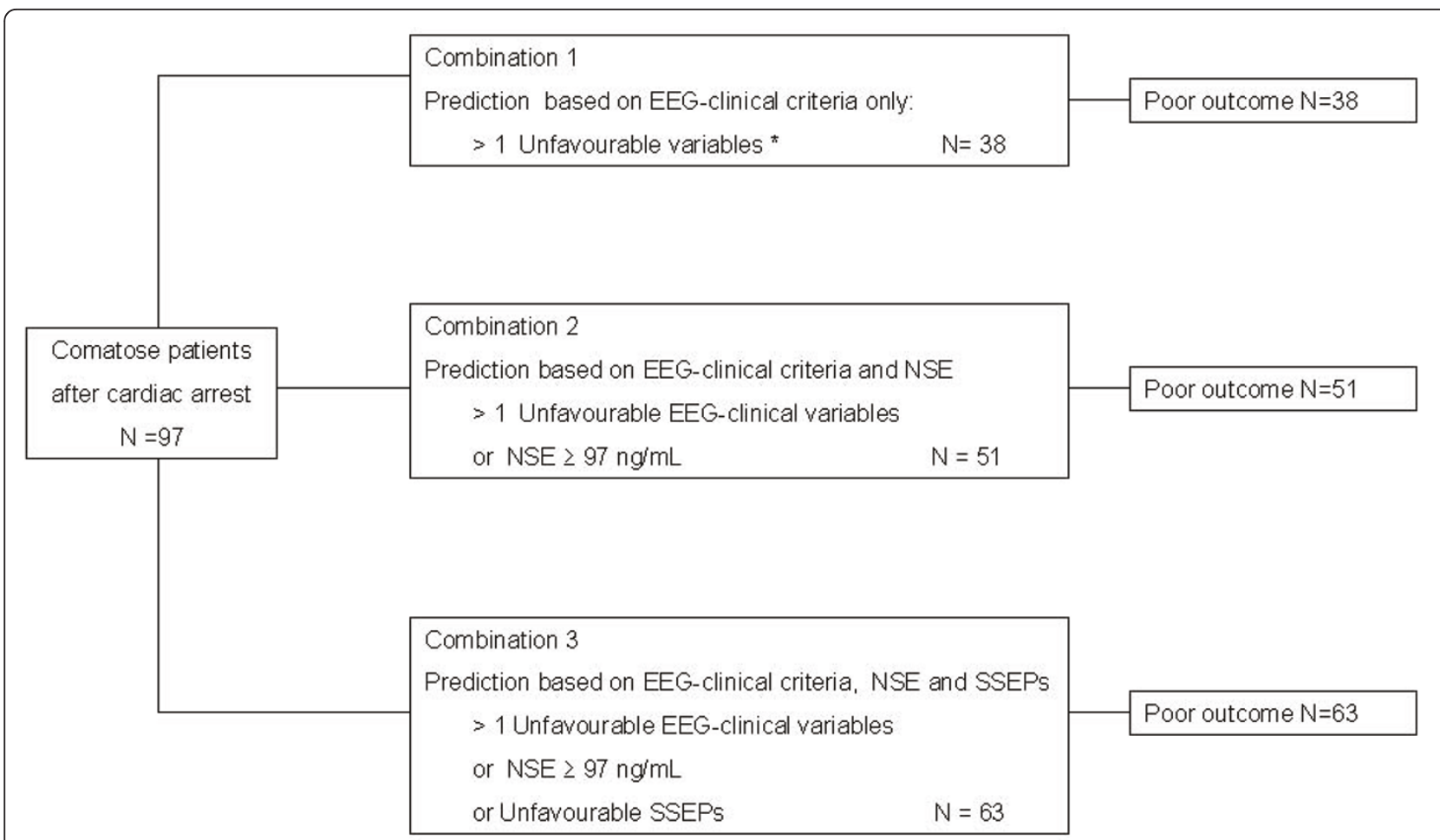

Figure 4 Predictors of poor outcome according to different clinical-EEG, NSE and SSEPs combinations. * included: myoclonus at $24 \mathrm{~h}$, and absence of pupillary light reflex or corneal reflex, tonic-clonic seizures and malignant EEG pattern at $72 \mathrm{~h}$.

However, the cut-off values for NSE with $100 \%$ predictive value of poor outcome determined in our study is rather high in comparison with others (range 9 to 91 $\mathrm{ng} / \mathrm{mL}$ ) previously reported (Table 3 ). Differences in selected patients (outside- or inside-hospital resuscitation, primary cause of cardiac arrest, initial rhythm, time of inclusion after cardiac arrest), definitions of poor outcome (death, Glasgow Coma Scale $<8$, absence of regaining of consciousness (CPC 4-5) or without return to normal social activity (CPC 3-5)), duration of follow up (hospital discharge, 1-month, 3-month or 6-month), time of blood sampling and assay procedures could explain these differences. Nevertheless, we consider that a poor outcome defined by CPC 4-5 is more accurate in a study assessing a cut-off value of a biomarker on which treatment withdrawal could be decided. In this context, except for references [2] and [10], cut-off values for NSE are highest (range 39 to $91 \mathrm{ng} / \mathrm{mL}$ ) in studies [15-19] with vegetative state or death as endpoints, in accordance with our results.

Whether hypothermia, performed in most of our patients, may affect NSE measurement is unclear. Recently, studies $[9,20]$ testing the predictive values for NSE to predict poor outcome (CPC 3-5) in comatose patients after cardiac arrest treated with therapeutic hypothermia, reported cut-off values for NSE, at $48 \mathrm{~h}$, of $28 \mathrm{ng} / \mathrm{mL}$ and $33 \mathrm{ng} / \mathrm{mL}$, respectively; a result no different from that reported by Zandbergen et al. in patients without therapeutic hypothermia [2]. In contrast, hypothermic therapy for prevention of hypoxic damage after cardiac arrest has been reported to decrease NSE levels in comparison with levels with normothermic therapy $[14,42]$. However, in these studies $[14,42]$, the cut-off values for NSE predicting a poor outcome (CPC 3-5) were significantly higher in patients treated with induced hypothermia than in patients without therapeutic hypothermia. In this setting, NSE levels were higher (but not significantly) in patients treated with induced hypothermia.

Therefore, considering decisions to continue treatment in comatose patients after cardiac arrest, the different cut-off values for NSE reported in the literature should be interpreted with caution as many patient, treatment, and assay-procedure related factors may influence NSE measurement. For example, if we had used the NSE threshold $>33 \mathrm{ng} / \mathrm{mL}$, defined by Zandbergen et al. [2] to withdraw treatment in patients remaining comatose $24 \mathrm{~h}$ after cardiac arrest, 10/25 (40\%) of our patients with a good outcome could have had false predictions of a poor outcome (death or vegetative state).

We also report that an approach based on a combination of electrophysiological, biological and clinical tests allowed to increase the number of patients identified as having a poor outcome (Figure 3), in accordance with 
Table 3 Comparison of NSE levels to predict poor outcome after cardiac arrest and referenced study profiles

\begin{tabular}{|c|c|c|c|c|c|c|c|c|c|c|}
\hline Référence & $\begin{array}{c}\text { In- } \\
\text { hospital } \\
\text { CPR (\%) }\end{array}$ & $\begin{array}{c}\text { Time of } \\
\text { inclusion } \\
\text { after CPR, } \\
\mathrm{n} \\
\end{array}$ & $\begin{array}{c}\text { Hypothermic } \\
\text { therapy, } \\
\text { n }\end{array}$ & $\begin{array}{l}\text { Follow- } \\
\text { up }\end{array}$ & $\begin{array}{c}\text { Poor outcome } \\
\text { definition, and } \\
\text { number } \\
n\end{array}$ & $\begin{array}{l}\text { Method used for NSE } \\
\text { measurement }\end{array}$ & $\begin{array}{c}\text { NSE } \\
\text { sampling } \\
\text { time }\end{array}$ & $\begin{array}{l}\text { Cut-off } \\
\text { value } \\
\text { (ng/mL) }\end{array}$ & $\mathrm{Se}$ & $\overline{S p}$ \\
\hline $\begin{array}{l}\text { Fogel et al. } \\
\text { [10] } 1997\end{array}$ & $\begin{array}{c}\text { Not } \\
\text { specified }\end{array}$ & $\begin{array}{c}\text { ICU } \\
\text { admission } \\
n=43\end{array}$ & No & $\begin{array}{c}3 \\
\text { months }\end{array}$ & $\begin{array}{c}\text { Remained } \\
\text { comatose } \\
n=25\end{array}$ & $\begin{array}{l}\text { Radioimmunoassay, } \\
\text { Pharmacia LKB }\end{array}$ & $\begin{array}{l}\text { Day } 0 \\
\text { Day } 1 \\
\text { Day } 2 \\
\text { Day } 3\end{array}$ & $\begin{array}{l}33 \\
33 \\
33 \\
33\end{array}$ & $\begin{array}{l}25 \\
60 \\
63 \\
65\end{array}$ & $\begin{array}{l}100 \\
100 \\
100 \\
100\end{array}$ \\
\hline $\begin{array}{l}\text { Martens et al. } \\
\text { [21] } 1998\end{array}$ & $\begin{array}{c}\text { Not } \\
\text { specified }\end{array}$ & $\begin{array}{l}>24 h \\
n=64\end{array}$ & No & $\begin{array}{c}6 \\
\text { months }\end{array}$ & $\begin{array}{c}\text { Remained } \\
\text { comatose } \\
\mathrm{n}=35\end{array}$ & $\begin{array}{c}\text { Radioimmunoassay, } \\
\text { Profilogen }\end{array}$ & $24 \mathrm{~h}$ & 20 & 51 & 89 \\
\hline $\begin{array}{l}\text { Schoerkhber } \\
\text { et al. [11] } \\
1999\end{array}$ & $\begin{array}{l}\text { Yes (not } \\
\text { specified) }\end{array}$ & $\begin{array}{l}>6 h \\
n=56\end{array}$ & No & $\begin{array}{c}6 \\
\text { months }\end{array}$ & $\begin{array}{l}\text { CPC 3-5 } \\
n=28\end{array}$ & $\begin{array}{l}\text { Radioimmunoassay, } \\
\text { Profilogen }\end{array}$ & $\begin{array}{c}12 \mathrm{~h} \\
24 \mathrm{~h} \\
48 \mathrm{~h} \\
72 \mathrm{~h} \\
\text { Peak NSE } \\
\text { level } 12- \\
72 \mathrm{~h}\end{array}$ & $\begin{array}{l}38 \\
40 \\
25 \\
17 \\
27\end{array}$ & $\begin{array}{c}18 \\
8 \\
48 \\
70 \\
29\end{array}$ & $\begin{array}{l}100 \\
100 \\
100 \\
100 \\
100\end{array}$ \\
\hline $\begin{array}{l}\text { Rosen et al. } \\
\text { [12] } 2001\end{array}$ & No & $\begin{array}{l}>24 h \\
n=66\end{array}$ & No & 1 year & $\begin{array}{l}\text { CPC 3-5 } \\
n=42\end{array}$ & $\begin{array}{l}\text { Imunoluminometric assay, } \\
\text { Byk Sangtec Diagnostica }\end{array}$ & $\begin{array}{l}\text { Day1 } \\
\text { Day2 } \\
\text { Day3 }\end{array}$ & $\begin{array}{l}25 \\
25 \\
25\end{array}$ & $\begin{array}{l}\text { NM } \\
\text { NM } \\
\text { NM }\end{array}$ & $\begin{array}{l}100 \\
100 \\
100\end{array}$ \\
\hline $\begin{array}{c}\text { Zingler et al. } \\
{[15] 2003}\end{array}$ & $\begin{array}{l}\text { Yes (not } \\
\text { specified) }\end{array}$ & $\begin{array}{c}I C U \\
\text { admission } \\
n=27\end{array}$ & No & $\begin{array}{c}3 \\
\text { months }\end{array}$ & $\begin{array}{c}\text { CPC 4-5 } \\
n=17\end{array}$ & $\begin{array}{c}\text { Immunoluminometric } \\
\text { assay, Byk Sangtec } \\
\text { Diagnostica }\end{array}$ & $\begin{array}{l}\text { Day1 } \\
\text { Day2 } \\
\text { Day3 } \\
\text { Day7 } \\
\end{array}$ & $\begin{array}{l}48 \\
43 \\
91 \\
39\end{array}$ & $\begin{array}{l}53 \\
91 \\
75 \\
57 \\
\end{array}$ & $\begin{array}{l}100 \\
100 \\
100 \\
100 \\
\end{array}$ \\
\hline $\begin{array}{l}\text { Tiainem et al. } \\
\text { [14] } 2003\end{array}$ & $\mathrm{No}^{*}$ & $\begin{array}{c}\mathrm{ICU} \\
\text { admission } \\
\mathrm{n}=70\end{array}$ & $\begin{array}{c}\text { Yes } \\
n=36\end{array}$ & $\begin{array}{c}6 \\
\text { months }\end{array}$ & $\begin{array}{l}\text { CPC 3-5 } \\
n=29\end{array}$ & $\begin{array}{l}\text { time-resolved } \\
\text { immunofluorometric assay } \\
\text { (DELFIA, Wallac) }\end{array}$ & $\begin{array}{c}24 \text { h HT/ } \\
\text { no HT } \\
36 \text { h HT/ } \\
\text { no HT } \\
48 \text { h HT/ } \\
\text { no HT }\end{array}$ & $\begin{array}{c}31 / 13 \\
26 / 13 \\
25 / 9\end{array}$ & $\begin{array}{c}22 / \\
59 \\
30 / \\
63 \\
25 / \\
76 \\
\end{array}$ & $\begin{array}{l}96 / \\
100 \\
96 / \\
100 \\
96 / \\
100 \\
\end{array}$ \\
\hline $\begin{array}{c}\text { Meynaar et } \\
\text { al. } \\
\text { [13] } 2003\end{array}$ & $\begin{array}{l}\text { Yes } \\
(23 \%)\end{array}$ & $\begin{array}{c}\mathrm{ICU} \\
\text { admission } \\
\mathrm{n}=110\end{array}$ & No & $\begin{array}{l}\text { Hospital } \\
\text { discharge }\end{array}$ & $\begin{array}{c}\text { Remained } \\
\text { comatose } \\
n=81\end{array}$ & $\begin{array}{l}\text { time-resolved } \\
\text { immunofluorometric assay } \\
\text { (DELFIA, Wallac) }\end{array}$ & $\begin{array}{c}\text { Peak NSE } \\
\text { level 24- } \\
48 \text { h }\end{array}$ & 25 & 59 & 100 \\
\hline $\begin{array}{l}\text { Pfeifer et al. } \\
{[16] 2005}\end{array}$ & $\begin{array}{l}\text { Yes } \\
(44 \%)\end{array}$ & $\begin{array}{l}>48 \mathrm{~h} \\
\mathrm{n}=97\end{array}$ & Not specified & Day 28 & $\begin{array}{l}\text { CPC 4-5 } \\
\mathrm{n}=70\end{array}$ & $\begin{array}{l}\text { Imunoluminometric assays, } \\
\text { Byk Sangtec Diagnostica }\end{array}$ & Day 3 & 65 & 50 & 96 \\
\hline $\begin{array}{l}\text { Rech at al. } \\
{[17] 2006}\end{array}$ & $\begin{array}{l}\text { Yes } \\
(100 \%)\end{array}$ & $\begin{array}{l}>12 h \\
n=45\end{array}$ & No & $\begin{array}{c}6 \\
\text { months }\end{array}$ & $\begin{array}{c}C P C 4-5 \\
n=34\end{array}$ & $\begin{array}{c}\text { Electrochemiluminescence } \\
\text { immunoassay, Roche } \\
\text { Mannheim }\end{array}$ & $\begin{array}{l}\text { Between } \\
12-36 \mathrm{~h}\end{array}$ & 60 & 35 & 100 \\
\hline $\begin{array}{c}\text { Zandbergen } \\
\text { et al } \\
{[2] 2006} \\
\end{array}$ & $\begin{array}{c}\text { Not } \\
\text { specified }\end{array}$ & $\begin{array}{l}>24 h \\
n=407\end{array}$ & $\begin{array}{l}\text { Yes (not } \\
\text { specified) }\end{array}$ & $\begin{array}{c}1 \\
\text { months }\end{array}$ & $\begin{array}{l}\text { CPC 4-5 } \\
n=356\end{array}$ & $\begin{array}{c}\text { Immunoluminometric } \\
\text { assay, Byk Sangtec } \\
\text { Diagnostica } \\
\end{array}$ & $\begin{array}{l}24 \mathrm{~h} \\
48 \mathrm{~h} \\
72 \mathrm{~h} \\
\end{array}$ & $\begin{array}{l}>33 \\
>33 \\
>33 \\
\end{array}$ & $\begin{array}{l}42 \\
52 \\
46 \\
\end{array}$ & $\begin{array}{l}100 \\
100 \\
100 \\
\end{array}$ \\
\hline $\begin{array}{l}\text { Auer et al. } \\
\text { [18] } 2006\end{array}$ & $\begin{array}{l}\text { Yes (not } \\
\text { specified) }\end{array}$ & $\mathrm{n}=17$ & Not specified & $\begin{array}{l}\text { Hospital } \\
\text { discharge }\end{array}$ & $\begin{array}{l}\text { Death } \\
n=9\end{array}$ & $\begin{array}{c}\text { Electrochemiluminescence } \\
\text { immunoassay, Roche } \\
\text { Mannheim }\end{array}$ & $48 \mathrm{~h}$ & 30 & 79 & 100 \\
\hline $\begin{array}{l}\text { Grubb et al. } \\
\text { [23] } 2007\end{array}$ & No & $\begin{array}{c}\mathrm{ICU} \\
\text { admission } \\
\mathrm{n}=143\end{array}$ & Not specified & $\begin{array}{l}\text { Hospital } \\
\text { discharge }\end{array}$ & Death & $\begin{array}{l}\text { Enzyme immunoassay, } \\
\text { Roche Diagnostics }\end{array}$ & $\begin{array}{c}12 \mathrm{~h} \\
24-48 \mathrm{~h} \\
72-96 \mathrm{~h} \\
\end{array}$ & $\begin{array}{c}\text { NM } \\
71 \\
\text { NM } \\
\end{array}$ & 14 & 100 \\
\hline $\begin{array}{c}\text { Reisinger et } \\
\text { al. } \\
\text { [19]2007 } \\
\end{array}$ & $\begin{array}{l}\text { Yes } \\
(44 \%)\end{array}$ & $\begin{array}{c}\mathrm{ICU} \\
\text { admission } \\
\mathrm{n}=177\end{array}$ & $\begin{array}{c}\text { Yes } \\
n=20\end{array}$ & $\begin{array}{c}6 \\
\text { months }\end{array}$ & $\begin{array}{l}\text { CPC 4-5 } \\
\mathrm{n}=59\end{array}$ & $\begin{array}{c}\text { Electrochemiluminescence } \\
\text { immunoassay, Roche } \\
\text { Mannheim }\end{array}$ & $\begin{array}{l}\text { Peak NSE } \\
\text { level } \\
\text { Day 0-4 } \\
\end{array}$ & 80 & 63 & 100 \\
\hline $\begin{array}{c}\text { Oksanen et } \\
\text { al. } \\
\text { [20] } 2009\end{array}$ & $\mathrm{No}^{*}$ & $\begin{array}{c}\text { ICU } \\
\text { admission } \\
\mathrm{n}=90\end{array}$ & $\begin{array}{c}\text { Yes } \\
\mathrm{n}=90\end{array}$ & $\begin{array}{c}6 \\
\text { months }\end{array}$ & $\begin{array}{l}\mathrm{CPC} 3-5 \\
\mathrm{n}=40\end{array}$ & $\begin{array}{c}\text { Electrochemiluminescence } \\
\text { immunoassay, Roche } \\
\text { Mannheim }\end{array}$ & $\begin{array}{l}24 \mathrm{~h} \\
48 \mathrm{~h}\end{array}$ & $\begin{array}{l}41 \\
33\end{array}$ & $\begin{array}{l}20 \\
43\end{array}$ & $\begin{array}{l}100 \\
100\end{array}$ \\
\hline $\begin{array}{c}\text { Rundgren et } \\
\text { al. } \\
\text { [9] } 2009\end{array}$ & $\begin{array}{l}\text { Yes } \\
(17 \%)\end{array}$ & $\begin{array}{c}\mathrm{ICU} \\
\text { admission } \\
\mathrm{n}=102 \\
\text { (for NSE } \\
\text { cohort) }\end{array}$ & $\begin{array}{c}\text { Yes } \\
n=102\end{array}$ & $\begin{array}{c}6 \\
\text { months }\end{array}$ & $\begin{array}{l}\text { CPC 3-5 } \\
n=46\end{array}$ & $\begin{array}{l}\text { Imunoluminometric assay, } \\
\text { DiaSorin }\end{array}$ & $\begin{array}{l}2 \mathrm{~h} \\
24 \mathrm{~h} \\
48 \mathrm{~h} \\
72 \mathrm{~h}\end{array}$ & $\begin{array}{l}31 \\
38 \\
28 \\
27\end{array}$ & $\begin{array}{c}6 \\
11 \\
67 \\
50\end{array}$ & $\begin{array}{l}100 \\
100 \\
100 \\
100\end{array}$ \\
\hline
\end{tabular}


Table 3 Comparison of NSE levels to predict poor outcome after cardiac arrest and referenced study profiles (Continued)

\begin{tabular}{|c|c|c|c|c|c|c|c|c|c|c|}
\hline $\begin{array}{l}\text { Shinozaki et } \\
\text { al. } \\
\text { [22] } 2009\end{array}$ & $\begin{array}{l}\text { Yes } \\
(27 \%)\end{array}$ & $\begin{array}{c}\mathrm{ICU} \\
\text { admission } \\
\mathrm{n}=80\end{array}$ & $\begin{array}{c}\text { Yes } \\
n=45\end{array}$ & $\begin{array}{c}6 \\
\text { months }\end{array}$ & $\begin{array}{l}\text { CPC 3-5 } \\
n=67\end{array}$ & $\begin{array}{l}\text { Immunoradiometric assay, } \\
\text { Profilogen, DiaSorin }\end{array}$ & $\begin{array}{c}\text { Admission } \\
6 \mathrm{~h} \\
24 \mathrm{~h}\end{array}$ & $\begin{array}{l}46 \\
66 \\
40\end{array}$ & $\begin{array}{l}14 \\
19 \\
72\end{array}$ & $\begin{array}{l}100 \\
100 \\
100\end{array}$ \\
\hline $\begin{array}{l}\text { Steffen et al } \\
\text { [42] } 2010\end{array}$ & $\begin{array}{l}\text { Yes } \\
(21 \%)\end{array}$ & $\begin{array}{c}\text { ICU } \\
\text { admission } \\
\mathrm{n}=240\end{array}$ & $\begin{array}{c}\text { Yes } \\
n=133\end{array}$ & $\begin{array}{c}\text { ICU } \\
\text { discharge }\end{array}$ & $\begin{array}{l}\text { CPC 3-5 } \\
n=147\end{array}$ & $\begin{array}{c}\text { Electrochemiluminescence } \\
\text { immunoassay, Roche } \\
\text { Mannheim }\end{array}$ & $\begin{array}{l}72 \text { h HT/ } \\
\text { no HT }\end{array}$ & $79 / 27$ & $\begin{array}{l}50 \\
80\end{array}$ & $\begin{array}{l}100 \\
100\end{array}$ \\
\hline $\begin{array}{l}\text { Present } \\
\text { study }\end{array}$ & $\begin{array}{l}\text { Yes } \\
(31 \%)\end{array}$ & $\begin{array}{l}>48 h \\
n=97\end{array}$ & $\begin{array}{c}\text { Yes } \\
n=65\end{array}$ & $\begin{array}{c}3 \\
\text { months }\end{array}$ & $\begin{array}{c}\text { CPC 4-5 } \\
n=72\end{array}$ & $\begin{array}{c}\text { Electrochemiluminescence } \\
\text { immunoassay, Roche } \\
\text { Mannheim }\end{array}$ & $\begin{array}{l}\text { Peak NSE } \\
\text { level 24- } \\
72 \mathrm{~h}\end{array}$ & 97 & 49 & 100 \\
\hline
\end{tabular}

HT; hypothermic therapy, NM; not mentioned

* Only ventricular fibrillation as initial rhythm was eligible for the study

" Results mentioned only for patients who remained comatose 48 hours after CPR ( $n=67)$

other studies $[2,8,13,15,16,19,27]$. Therefore, based on all available evidence [1-24,27,30,32-40] and our current results, we suggest the following strategy to help clinicians determine the level of care to be provided in patients remaining comatose three days after cardiac arrest: when the cortical response (N20) to SSEPs is bilaterally absent, further treatment should be considered futile and active care withdrawn. When the SSEP recording is equivocal, it must be repeated. When SSEPs are favourable or when SSEPs are not accessible, the presence of more than one pejorative EEG-biologicalclinical criterion at day 3 should be considered sufficient to forego further treatment; these include: serum NSE > $97 \mathrm{ng} / \mathrm{mL}$, malignant EEG pattern (burst-suppression with or without epileptiform discharge or isoelectric pattern), absence of pupillary light reflex or corneal reflex, and persistence of tonic-clonic seizures or myoclonus. Moreover, we would like to emphasize that no tests are available that can reliably predict recovery of consciousness or the quality of life in survivors. Nevertheless, a recent study reported that continuous amplitude-integrated electroencephalogram added valuable positive and negative prognostic information in hypothermiatreated cardiac arrest patients [43].

This study has some limitations. Firstly, the relative small sample size may limit the interpretation and relevance of the cut-off value for NSE. In addition, because of differences in NSE measurements obtained using assays from different manufacturers (Table 3), the cutoff values for NSE reported in this setting should be interpreted with caution. Secondly, hemolysis due to renal replacement therapy needed for 15 patients at ICU admission may affect the cut-off value for NSE. However, we believe the effect of this hemolysis was limited because the highest measurement of NSE was significantly lower in patients with renal replacement therapy $(59 \mathrm{ng} / \mathrm{mL}$ [IQR, 35-112] versus $67 \mathrm{ng} / \mathrm{mL}$ [IQR, 34$159], p=0.025)$. Thirdly, the applicability of our findings could be limited because of early withdrawal of treatment for patients with poor prognoses, which could result in a self-fulfilling prophesy of poor outcome. However, all of our patients were actively supported without restriction during the first days following cardiac arrest or until SSEPs were assessed, and only a lack of bilateral cortical response to SSEPs associated with pejorative clinical-EEG criteria in all cases in our study, or the presence of 3 or more predefined pejorative clinical-EEG criteria, recognised to predict a worse outcome $[1,2,30]$, could lead to active care withdrawal. In addition, because our study focuses specifically on comatose patients after cardiac arrest for whom there is an ethical question of whether to continue treatment, we believe that this report adds useful information about clinical outcome and predictors of death or vegetative state in this setting.

\section{Conclusion}

We show that NSE levels, measured early in the course of patient care for those who remained comatose 3 days after cardiac arrest, are significantly higher in patients with a poor outcome (death or vegetative state). In addition, we provide a cut-off value $(>97 \mathrm{ng} / \mathrm{mL})$ for NSE, with $100 \%$ predictive value for a poor outcome. Nevertheless, considering decisions to continue treatment in this setting, we emphasize that cut-off values for NSE presented in the literature should be interpreted with caution and that an approach based on a combination of SSEPs, NSE and clinical-EEG tests would be the most accurate for early identification of a subgroup of irrecoverable patients for whom intensive treatment could be regarded as futile and palliative care only could be provided.

\section{Author information}

This work was presented in part at the annual congress of the Société de Réanimation de Langue Française (SRLF) held in January 2010, Paris, France.

This study was funded by an academic unrestricted grant (Appel d'Offre Interne) from the Caen Côte de Nacre University hospital. 


\section{Additional material}

Additional file 1: " Receiver operating characteristic curves for $72 \mathrm{~h}$ NSE values $(\mathrm{ng} / \mathrm{mL})$ to predict poor neurological outcome. This file highlight that considering 72 h-NSE values $(n=61)$, a level $\geq 68 \mathrm{ng} / \mathrm{mL}$ predicted a poor outcome (CPC 4-5) with a positive predictive value of $100 \%[95 \% \mathrm{IC}=100 \%-100 \%]$ and a sensitivity of $67 \%[95 \% \mathrm{IC}=54 \%$ $81 \%]$.

\section{Abbreviations}

EEG: Electro-Encephalography; GPCPC: Glasgow-Pittsburgh Cerebral Performance Category; NSE: Neuron-Specific Enolase; SSEPs: Somatosensory Evoked Potentials; ROC: Receiver Operating Characteristics.

\section{Acknowledgements}

We thank Ms. Valerie Fong-Constans for her contribution in polishing the manuscript.

\begin{abstract}
Author details
'Department of Medical Intensive Care, CHU de Caen, Caen, F-14000, France. ${ }^{2}$ Department of Medical Intensive Care, Mémorial France-Etats-Unis Hospital, Saint-Lô, France. ${ }^{3}$ Department of Biochemistry, CHU de Caen, Caen, F-14000, France. ${ }^{4}$ UPRES EA 3919, CHU de Caen, Caen University, Caen, F-14000, France. ${ }^{5}$ Laboratory of Neurological Functional Exploratory, CHU de Caen, Caen, F-14000, France. ${ }^{6}$ Department of Biostatistics and Clinical Research, CHU de Caen, Caen, F-14000, France. ${ }^{7}$ INSERM, UMR-S 707, Paris, F-75012, France. ${ }^{8}$ INSERM, ERI27, Caen, F-14000 France; Univ Caen, Caen, F-14000 France; CHRU Caen, Department of Medical Intensive Care, Caen, F-14000, France. ${ }^{9}$ E.A. 4497, Université de Versailles-Saint Quentin en Yvelines, 92380 Garches, France. ${ }^{10}$ UPRES, EA 2128, Caen, F-14000, France.
\end{abstract}

\section{Authors' contributions}

CD and CQ initiated the study, and the design. SA performed NSE measurement. OE read all EEGs and SSEPS. JJP, CG and CD performed the statistical analysis and were involved in the interpretation of the results. $C D$ and $C Q$ wrote the manuscript, and JJP and PC helped to draft the manuscript. AS, XV, FP, MR, NT, OE, SA and DDC, contributed to the conception and design of the study and revision of the manuscript. All authors read and approved the final manuscript.

\section{Competing interests}

The authors declare that they have no competing interests.

Received: 25 February 2011 Accepted: 8 August 2011

Published: 8 August 2011

\section{References}

1. Wijdicks Neurology 2006 13these Wijdicks EF, Hijdra A, Young GB, Bassetti CL, Wiebe S: Practice parameter: prediction of outcome in comatose survivors after cardiopulmonary resuscitation (an evidencebased review): report of the Quality Standards Subcommittee of the American Academy of Neurology. Neurology 2006, 67:203-210.

2. Zandbergen EG, Hijdra A, Koelman JH, Hart AA, Vos PE, Verbeek MM, de Haan RJ, PROPAC Study Group: Prediction of poor outcome within the first 3 days of postanoxic coma. Neurology 2006, 66:62-68.

3. Tiainen M, Kovala TT, Takkunen OS, Roine RO: Somatosensory and brainstem auditory evoked potentials in cardiac arrest patients treated with hypothermia. Crit Care Med 2005, 33:1736-1740.

4. Koht A, Schatz W, Schmidt G, Schramm J, Watanabe E: Effects of etomidate, midazolam, and thiopental on median nerve somatosensory evoked potentials and the additive effects of fentanyl and nitrous oxide. Anesth Analg 1988, 67:435-441.

5. Sloan TB, Fugina ML, Toleikis JR: Effects of midazolam on median nerve somatosensory evoked potentials. Br J Anaesth 1990, 64:590-593.

6. Stecker MM, Cheung AT, Pochettino A, Kent GP, Patterson T, Weiss SJ, Bavaria JE: Deep hypothermic circulatory arrest: I. Effects of cooling on electroencephalogram and evoked potentials. Ann Thorac Surg 2001, 71:14-21.
7. Kottenberg-Assenmacher E, Armbruster W, Bornfeld N, Peters J: Hypothermia does not alter somatosensory evoked potential amplitude and global cerebral oxygen extraction during marked sodium nitroprusside-induced arterial hypotension. Anesthesiology 2003, 98:1112-1118.

8. Zandbergen EG, de Haan RJ, Stoutenbeek CP, Koelman JH, Hijdra A: Systematic review of early prediction of poor outcome in anoxic ischaemic coma. Lancet 1998, 352:1808-1812.

9. Rundgren M, Karlsson T, Nielsen N, Cronberg T, Johnsson P, Friberg $\mathrm{H}$ : Neuron specific enolase and S-100B as predictors of outcome after cardiac arrest and induced hypothermia. Resuscitation 2009, 80:784-789.

10. Fogel W, Krieger D, Veith M, Adams HP, Hund E, Storch-Hagenlocher B, Buggle F, Mathias D, Hacke W: Serum neuron-specific enolase as early predictor of outcome after cardiac arrest. Crit Care Med 1997, 25:1133-1138.

11. Schoerkhuber W, Kittler H, Sterz F, Behringer W, Holzer M, Frossard M, Spitzauer S, Laggner AN: Time course of serum neuron-specific enolase. A predictor of neurological outcome in patients resuscitated from cardiac arrest. Stroke 1999, 30:1598-1603.

12. Rosén H, Sunnerhagen KS, Herlitz J, Blomstrand C, Rosengren L: Serum levels of the brain-derived proteins S-100 and NSE predict long-term outcome after cardiac arrest. Resuscitation 2001, 49:183-191.

13. Meynaar IA, Oudemans-van Straaten HM, van der Wetering J, Verlooy P, Slaats EH, Bosman RJ, van der Spoel Jl, Zandstra DF: Serum neuron-specific enolase predicts outcome in post-anoxic coma: a prospective cohort study. Intensive Care Med 2003, 29:189-195.

14. Tiainen M, Roine RO, Pettilä $V$, Takkunen O: Serum neuron-specific enolase and S-100B protein in cardiac arrest patients treated with hypothermia. Stroke 2003, 34:2881-2886.

15. Zingler VC, Krumm B, Bertsch T, Fassbender K, Pohlmann-Eden B: Early prediction of neurological outcome after cardiopulmonary resuscitation: a multimodal approach combining neurobiochemical and electrophysiological investigations may provide high prognostic certainty in patients after cardiac arrest. Eur Neurol 2003, 49:79-84.

16. Pfeifer R, Börner A, Krack A, Sigusch HH, Surber R, Figulla HR: Outcome after cardiac arrest: predictive values and limitations of the neuroproteins neuron-specific enolase and protein S-100 and the Glasgow Coma Scale. Resuscitation 2005, 65:49-55.

17. Rech TH, Vieira SR, Nagel F, Brauner JS, Scalco R: Serum neuron-specific enolase as early predictor of outcome after in-hospital cardiac arrest: a cohort study. Crit Care 2006, 10:R133.

18. Auer J, Berent R, Weber T, Porodko M, Lamm G, Lassnig E, Maurer E, Mayr H, Punzengruber C, Eber B: Ability of neuron-specific enolase to predict survival to hospital discharge after successful cardiopulmonary resuscitation. CJEM 2006, 8:13-18

19. Reisinger J, Höllinger K, Lang W, Steiner C, Winter T, Zeindlhofer E, Mori M, Schiller A, Lindorfer A, Wiesinger K, Siostrzonek P: Prediction of neurological outcome after cardiopulmonary resuscitation by serial determination of serum neuron-specific enolase. Eur Heart J 2007, 28:52-58.

20. Oksanen T, Tiainen M, Skrifvars MB, Varpula T, Kuitunen A, Castrén M, Pettilä V: Predictive power of serum NSE and OHCA score regarding 6month neurologic outcome after out-of-hospital ventricular fibrillation and therapeutic hypothermia. Resuscitation 2009, 80:165-170.

21. Martens P, Raabe A, Johnsson P: Serum S-100 and neuron-specific enolase for prediction of regaining consciousness after global cerebral ischemia. Stroke 1998, 29:2363-2366.

22. Shinozaki K, Oda S, Sadahiro T, Nakamura M, Abe R, Nakada TA, Nomura F, Nakanishi K, Kitamura N, Hirasawa H!: Serum S-100B is superior to neuronspecific enolase as an early prognostic biomarker for neurological outcome following cardiopulmonary resuscitation. Resuscitation 2009, 80:870-875.

23. Grubb NR, Simpson C, Sherwood RA, Abraha HD, Cobbe SM, O'Carroll RE, Deary I, Fox KA: Prediction of cognitive dysfunction after resuscitation from out-of-hospital cardiac arrest using serum neuron-specific enolase and protein S-100. Heart 2007, 93:1268-1273.

24. Cummins RO, Chamberlain DA, Abramson NS, Allen M, Baskett $P$, Becker L, Bossaert L, Delooz H, Dick W, Eisenberg M: Recommended guidelines for uniform reporting of data from out-of-hospital cardiac arrest: the Utstein Style. Task Force of the American Heart Association, the European Resuscitation Council, the Heart and Stroke 
Foundation of Canada, and the Australian Resuscitation Council. Ann Emerg Med 1991, 20:861-874.

25. Le Gall JR, Lemeshow S, Saulnier F: A new Simplified Acute Physiology Score (SAPS II) based on a European/North American multicenter study. JAMA 1993, 270:2957-2963.

26. Knaus WA, Draper EA, Wagner DP, Zimmerman JE: Prognosis in acute organ-system failure. Ann Surg 1985, 202:685-693.

27. Daubin C, Guillotin D, Etard O, Gaillard C, du Cheyron D, Ramakers M, Bouchet B, Parienti JJ, Charbonneau P: A clinical and EEG scoring system that predicts early cortical response (N20) to somatosensory evoked potentials and outcome after cardiac arrest. BMC Cardiovasc Disord 2008, 8:35.

28. Synek VM: EEG abnormality grades and subdivisions of prognostic importance in traumatic and anoxic coma in adults. Clin Electroencephalogr 1988, 19:160-166.

29. Synek VM: Prognostically important EEG coma patterns in diffuse anoxic and traumatic encephalopathies in adults. J Clin Neurophysiol 1988, 5:161-174.

30. Thömke F, Marx JJ, Sauer O, Hundsberger T, Hägele S, Wiechelt J, Weilemann SL: Observations on comatose survivors of cardiopulmonary resuscitation with generalized myoclonus. BMC Neurol 2005, 5:14.

31. Simel DL, Samsa GP, Matchar DB: Likelihood ratios with confidence: sample size estimation for diagnostic test studies. J Clin Epidemiol 1991, 44:763-770.

32. Levy DE, Caronna JJ, Singer BH, Lapinski RH, Frydman H, Plum F: Predicting outcome from hypoxic-ischemic coma. JAMA 1985, 253:1420-1426.

33. Edgren E, Hedstrand U, Kelsey S, Sutton-Tyrrell K, Safar P: Assessment of neurological prognosis in comatose survivors of cardiac arrest. BRCT I Study Group. Lancet 1994, 343:1055-1059.

34. Chen R, Bolton CF, Young B: Prediction of outcome in patients with anoxic coma: a clinical and electrophysiologic study. Crit Care Med 1996, 24:672-678.

35. Fischer C, Luauté J, Némoz C, Morlet D, Kirkorian G, Mauguière F: Improved prediction of awakening or nonawakening from severe anoxic coma using tree-based classification analysis. Crit Care Med 2006, 34:1520-1524

36. Jorgensen EO, Holm S, Resuscitation: The natural course of neurological recovery following cardiopulmonary. Resuscitation 1998, 36:111-122.

37. Madl C, Kramer L, Domanovits H, Woolard RH, Gervais $\mathrm{H}$, Gendo A, Eisenhuber E, Grimm G, Sterz F: Improved outcome prediction in unconscious cardiac arrest survivors with sensory evoked potentials compared with clinical assessment. Crit Care Med 2000, 28:721-6.

38. Nakabayashi M, Kurokawa A, Yamamoto Y: Immediate prediction of recovery of consciousness after cardiac arrest. Intensive Care Med 2001, 27:1210-1214.

39. Robinson LR, Micklesen PJ, Tirschwell DL, Lew HL: Predictive value of somatosensory evoked potentials for awakening from coma. Crit Care Med 2003, 31:960-967.

40. Madl C, Grimm G, Kramer L, Yeganehfar W, Sterz F, Schneider B, Kranz A, Schneeweiss B, Lenz K: Early prediction of individual outcome after cardiopulmonary resuscitation. Lancet 1993, 341:855-858.

41. Rossetti AO, Oddo M, Logroscino G, Kaplan PW: Prognostication after cardiac arrest and hypothermia: a prospective study. Ann Neurol 2010, 67:301-307.

42. Steffen IG, Hasper D, Ploner CJ, Schefold JC, Dietz E, Martens F, Nee J, Krueger A, Jörres A, Storm C: Mild therapeutic hypothermia alters neuron specific enolase as an outcome predictor after resuscitation: 97 prospective hypothermia patients compared to 133 historical nonhypothermia patients. Crit Care 2010, 14:R69.

43. Rundgren M, Westhall E, Cronberg T, Rosén I, Friberg H: Continuous amplitude-integrated electroencephalogram predicts outcome in hypothermia-treated cardiac arrest patients. Crit Care Med 2010, 38:1838-1844.

\section{Pre-publication history}

The pre-publication history for this paper can be accessed here: http://www.biomedcentral.com/1471-2261/11/48/prepub

\section{doi:10.1186/1471-2261-11-48}

Cite this article as: Daubin et al:: Serum neuron-specific enolase as predictor of outcome in comatose cardiac-arrest survivors: a prospective cohort study. BMC Cardiovascular Disorders 2011 11:48.

\section{Submit your next manuscript to BioMed Central and take full advantage of:}

- Convenient online submission

- Thorough peer review

- No space constraints or color figure charges

- Immediate publication on acceptance

- Inclusion in PubMed, CAS, Scopus and Google Scholar

- Research which is freely available for redistribution 